\title{
Phase-stabilization and substrate effects on nucleation and growth of $(\mathrm{Ti}, \mathrm{V})(\mathrm{n}+1) \mathrm{GeC}(\mathrm{n})$ thin films
}

\author{
Sit Kerdsongpanya, Kristina Buchholt, Olof Tengstrand, Jun Lu, \\ Jens Jensen, Lars Hultman and Per Eklund
}

\section{Linköping University Post Print}

N.B.: When citing this work, cite the original article.

Original Publication:

Sit Kerdsongpanya, Kristina Buchholt, Olof Tengstrand, Jun Lu, Jens Jensen, Lars Hultman and Per Eklund, Phase-stabilization and substrate effects on nucleation and growth of $(\mathrm{Ti}, \mathrm{V})(\mathrm{n}+1) \mathrm{GeC}(\mathrm{n})$ thin films, 2011, Journal of Applied Physics, (110), 5, 053516. http://dx.doi.org/10.1063/1.3631087

Copyright: American Institute of Physics (AIP) http://www.aip.org/

Postprint available at: Linköping University Electronic Press http://urn.kb.se/resolve?urn=urn:nbn:se:liu:diva-71221 


\section{AIP \\ stont Applied Physics}

Phase-stabilization and substrate effects on nucleation and growth of $(\mathrm{Ti}, \mathrm{V}) \mathbf{n}+\mathbf{1 G e C n}$ thin films

Sit Kerdsongpanya, Kristina Buchholt, Olof Tengstrand, Jun Lu, Jens Jensen et al.

Citation: J. Appl. Phys. 110, 053516 (2011); doi: 10.1063/1.3631087

View online: http://dx.doi.org/10.1063/1.3631087

View Table of Contents: http://jap.aip.org/resource/1/JAPIAU/v110/i5

Published by the American Institute of Physics.

\section{Related Articles}

Role of interfacial transition layers in VO2/AI2O3 heterostructures J. Appl. Phys. 110, 073515 (2011)

Effects of stress on the optical properties of epitaxial Nd-doped Sr0.5Ba0.5Nb2O6 films AIP Advances 1, 032172 (2011)

Polycrystalline iron nitride films fabricated by reactive facing-target sputtering: Structure, magnetic and electrical transport properties

J. Appl. Phys. 110, 053911 (2011)

Growth of a crystalline and ultrathin $\mathrm{MgO}$ film on $\mathrm{Fe}(001)$

AIP Advances 1, 032156 (2011)

Structural and magnetic properties of quaternary Co2Mn1-xCrxSi Heusler alloy thin films J. Appl. Phys. 110, 053903 (2011)

\section{Additional information on J. Appl. Phys.}

Journal Homepage: http://jap.aip.org/

Journal Information: http://jap.aip.org/about/about_the_journal

Top downloads: http://jap.aip.org/features/most_downloaded

Information for Authors: http://jap.aip.org/authors

\section{ADVERTISEMENT}

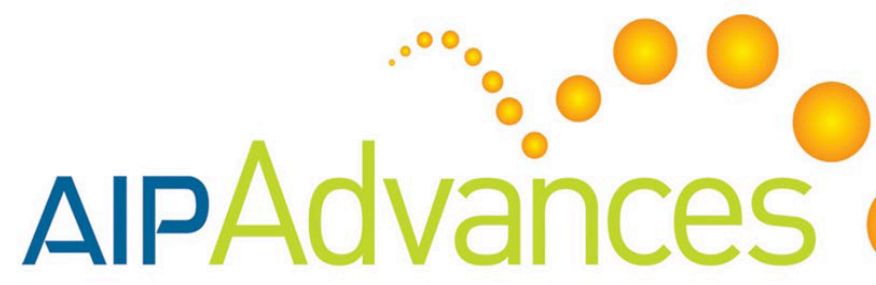

Submit Now
Explore AIP's new open-access journal

Article-level metrics now available

Join the conversation! Rate \& comment on articles 


\title{
Phase-stabilization and substrate effects on nucleation and growth of $(\mathrm{Ti}, \mathrm{V})_{n+1} \mathrm{GeC}_{n}$ thin films
}

\author{
Sit Kerdsongpanya, ${ }^{\text {a) }}$ Kristina Buchholt, Olof Tengstrand, Jun Lu, Jens Jensen, \\ Lars Hultman, and Per Eklund \\ Thin Film Physics Division, Department of Physics, Chemistry, and Biology, IFM, Linköping University, \\ SE-581 83 Linköping, Sweden
}

(Received 16 June 2011; accepted 26 July 2011; published online 12 September 2011)

\begin{abstract}
Phase-pure epitaxial thin films of $(\mathrm{Ti}, \mathrm{V})_{2} \mathrm{GeC}$ have been grown onto $\mathrm{Al}_{2} \mathrm{O}_{3}(0001)$ substrates via magnetron sputtering. The $c$ lattice parameter is determined to be $12.59 \AA$, corresponding to a 50/50 Ti/V solid solution according to Vegard's law, and the overall (Ti,V):Ge:C composition is 2:1:1 as determined by elastic recoil detection analysis. The minimum temperature for the growth of $(\mathrm{Ti}, \mathrm{V})_{2} \mathrm{GeC}$ is $700{ }^{\circ} \mathrm{C}$, which is the same as for $\mathrm{Ti}_{2} \mathrm{GeC}$ but higher than that required for $\mathrm{V}_{2} \mathrm{GeC}$ $\left(450{ }^{\circ} \mathrm{C}\right)$. Reduced $\mathrm{Ge}$ content yields films containing $(\mathrm{Ti}, \mathrm{V})_{3} \mathrm{GeC}_{2}$ and $(\mathrm{Ti}, \mathrm{V})_{4} \mathrm{GeC}_{3}$. These results show that the previously unknown phases $\mathrm{V}_{3} \mathrm{GeC}_{2}$ and $\mathrm{V}_{4} \mathrm{GeC}_{3}$ can be stabilized through alloying with Ti. For films grown on $4 \mathrm{H}-\mathrm{SiC}(0001),(\mathrm{Ti}, \mathrm{V})_{3} \mathrm{GeC}_{2}$ was observed as the dominant phase, showing that the nucleation and growth of $(\mathrm{Ti}, \mathrm{V})_{\mathrm{n}}+{ }_{1} \mathrm{GeC}_{\mathrm{n}}$ is affected by the choice of substrate; the proposed underlying physical mechanism is that differences in the local substrate temperature enhance surface diffusion and facilitate the growth of the higher-order phase $(\mathrm{Ti}, \mathrm{V})_{3} \mathrm{GeC}_{2}$ compared to $(\mathrm{Ti}, \mathrm{V})_{2} \mathrm{GeC}$. (C) 2011 American Institute of Physics. [doi:10.1063/1.3631087]
\end{abstract}

\section{INTRODUCTION}

The class of ternary nitrides and carbides known as $M_{n+1} A_{n}$ phases $(n=1,2,3)$ comprises compounds made of M (a transition metal); an element from groups 12-16 (A), usually group 13 or 14 ; and a third element, $\mathrm{X}$, that is either nitrogen or carbon. ${ }^{1-3} \mathrm{MAX}$ phases are divided into three subgroups: $\mathrm{M}_{2} \mathrm{AX}, \mathrm{M}_{3} \mathrm{AX}_{2}$, and $\mathrm{M}_{4} \mathrm{AX}$, or "211," "312," and " 413 " phases, respectively. Recently, $(\mathrm{Ti}, \mathrm{Nb})_{5} \mathrm{AlC}_{4}$, the first example of a "514" phase, was discovered by Zheng et $a l^{4}$. The MAX phases' unusual anisotropic hexagonal nanolaminated structure give remarkable properties such as high resistance to thermal shock, machinability, ductility, and high thermal and electrical conductivity. ${ }^{1,2}$

Among the research topics related to MAX phases, solid solutions are interesting because the effect of chemistry on synthesis, phase stability, and properties can be studied. ${ }^{3,5}$ These solid solutions can be categorized in three groups: (i) M-site solutions $(\mathrm{M} 1, \mathrm{M} 2)_{\mathrm{n}+1} \mathrm{AX}_{\mathrm{n}}$, (ii) A-site solid solutions $M_{n+1}(A 1, A 2) X_{n}$, and (iii) X-site solutions $M_{n+1} A(X 1, X 2){ }_{n}{ }^{2}$ Different MAX-phase solid solutions have been investigated as bulk materials (e.g., Refs. 1, 5-9). However, solid solution MAX-phase thin films have been studied much less and offer an important opportunity for exploration, as it is relatively easy to grow MAX phases epitaxially, ${ }^{10-16}$ and thin-film growth permits the study of materials that are metastable and difficult to synthesize in bulk. ${ }^{2}$ Among the relatively few studies that exist on MAX-phase solid solutions in thin films, Scabarozi et al. reported $\mathrm{M}$-site solid solutions of $(\mathrm{Ti}, \mathrm{Nb}){ }_{2} \mathrm{AlC}$ thin films. ${ }^{17}$ From Raman scattering, they indirectly determined the elastic modulus, suggesting solid solution hardening. Furthermore, in thin films, the oxycarbide X-site solid

\footnotetext{
a) Author to whom correspondence should be addressed. Electronic mail: sitke@ifm.liu.se.
}

solution $\mathrm{Ti}_{2} \mathrm{Al}(\mathrm{C}, \mathrm{O})$ has been reported as a result of the incorporation of oxygen from the residual gas in a vacuum deposition process ${ }^{18}$ or due to a reaction between $\mathrm{TiC}$ or $\mathrm{Ti}_{2} \mathrm{AlC}$ layers with an $\mathrm{Al}_{2} \mathrm{O}_{3}$ substrate. ${ }^{19,20}$

Here, we investigate the $\mathrm{Ti}-\mathrm{V}-\mathrm{Ge}-\mathrm{C}$ system. The end members $\mathrm{Ti}_{2} \mathrm{GeC}$ and $\mathrm{V}_{2} \mathrm{GeC}$ exist in bulk ${ }^{1,2}$ and have also been grown as thin-film materials. ${ }^{14,21-25}$ However, the two systems differ in that the Ti-Ge-C system contains two other MAX phases $\left(\mathrm{Ti}_{3} \mathrm{GeC}_{2}\right.$ and $\left.\mathrm{Ti}_{4} \mathrm{GeC}_{3}\right)$, ${ }^{2,24}$ whereas the V-Ge$\mathrm{C}$ system does not contain them, and in that the lowest reported growth temperature required in order to form $\mathrm{Ti}_{2} \mathrm{GeC}$ is $\sim 700{ }^{\circ} \mathrm{C}\left(\sim 800{ }^{\circ} \mathrm{C}\right.$ for phase-pure $\left.\mathrm{Ti}_{2} \mathrm{GeC}\right)$, whereas $\mathrm{V}_{2} \mathrm{GeC}$ can be grown at temperatures down to $\sim 450$ ${ }^{\circ} \mathrm{C}$. The Ti-V-Ge-C system is therefore an ideal model system for investigating whether the " 312 " and " 413 " phases can be stabilized in the V-Ge-C system by alloying with Ti, and for determining whether the growth temperature of $(\mathrm{Ti}, \mathrm{V})_{2} \mathrm{GeC}$ can be substantially reduced compared to that of $\mathrm{Ti}_{2} \mathrm{GeC}$.

\section{EXPERIMENTAL DETAILS}

The $(\mathrm{Ti}, \mathrm{V})_{2} \mathrm{GeC}$ thin films were deposited using dc magnetron sputtering in an ultrahigh vacuum chamber (base pressure lower than $10^{-7} \mathrm{~Pa}$ ) in an $\mathrm{Ar}(99.9999 \%)$ discharge at a pressure of $\sim 0.5 \mathrm{~Pa}$. Three targets were used for the depositions: $\mathrm{Ti} / \mathrm{V}(50$ at. $\% / 50$ at. $\%, 99.9 \%$ purity), Ge (99.99\% purity), and graphite $(99.99 \%$ purity), with diameters of 75,50 , and $75 \mathrm{~mm}$, respectively. The targets were operated in current-control mode with $(\mathrm{Ti}, \mathrm{V})$ at $310 \mathrm{~mA}$ $(\sim 311 \mathrm{~V}), \mathrm{Ge}$ at 50 to $70 \mathrm{~mA}(\sim 333-340 \mathrm{~V})$, and $\mathrm{C}$ at 370 to $400 \mathrm{~mA}(\sim 630-722 \mathrm{~V})$. The substrate temperature $\left(\mathrm{T}_{\mathrm{s}}\right)$ was varied in the range of $350-800{ }^{\circ} \mathrm{C}$. Details about the deposition system can be found elsewhere. ${ }^{10}$

The substrates were $(12.5 \times 12.5) \mathrm{mm}^{2}$ of $\mathrm{Al}_{2} \mathrm{O}_{3}(0001)$, single-side polished, and a $4 \mathrm{H}-\mathrm{SiC}(0001)$ n-type wafer, 
Si-face, cut $4^{\circ}$ off-axis, from SiCrystal. ${ }^{26}$ The $4 \mathrm{H}-\mathrm{SiC}(0001)$ substrate has a $1 \mu \mathrm{m}$ thick $p$ - $\left(4 \times 10^{15} \mathrm{~cm}^{-3}\right)$ doped epitaxially grown $\mathrm{SiC}$ layer with a $0.8 \mu \mathrm{m} \mathrm{n}$ - $\left(1.5 \times 10^{19} \mathrm{~cm}^{-3}\right)$ doped epitaxially grown $\mathrm{SiC}$ layer on top. The dopant atoms used for the epilayers were $\mathrm{Al}$ and $\mathrm{N}$ for the $p$ - and $n$-type, respectively, and were grown at the Institute Acreo. ${ }^{27}$ Prior to deposition, the substrates were ultrasonically degreased in two steps-in acetone for $5 \mathrm{~min}$ and isopropanol for $5 \mathrm{~min}$ and blown dry in $\mathrm{N}_{2}$, inserted into the chamber, and thermally degassed at the substrate temperature for $1 \mathrm{~h}$. $4 \mathrm{H}-\mathrm{SiC}$ substrates were plasma etched for $30 \mathrm{~min}$ to remove any surface oxides on the $4 \mathrm{H}-\mathrm{SiC}$ (as in Ref. 28).

The structural characterization of as-deposited films was performed via $\mathrm{x}$-ray diffraction (XRD) $\theta-2 \theta$ scans using $\mathrm{Cu}$ $\mathrm{K}_{\alpha}$ as an X-ray source with a Philips PW 1820 diffractometer. The (0004) $4 \mathrm{H}-\mathrm{SiC}$ was aligned at an offset of $\sim 4^{\circ}$, because the $4 \mathrm{H}-\mathrm{SiC}$ substrate is cut $4^{\circ}$ off-axis. A Leo $1550 \mathrm{Gemini}$ scanning electron microscope (SEM) with an accelerating voltage of $5 \mathrm{kV}$ was used to study the surface morphology with secondary-electron images. A Dimension 3100 atomic force microscope (AFM) was also used to investigate the surface morphology. Transmission electron microscope (TEM) cross-sectional samples were prepared via mechanical polishing followed by ion milling in a Gatan Precision Ion Polishing System using argon ions with an energy of $5 \mathrm{keV}$, with a final polishing step at $2 \mathrm{keV}$. The TEM was an FEI Tecnai G2 TF 20 UT with a field-emission gun operated at an acceleration voltage of $200 \mathrm{keV}$. Time-of-flight elastic recoil detection analysis (ERDA) was applied in order to obtain the elemental depth profiles of the as-deposited films. The measurements were performed with a $40 \mathrm{MeV}{ }^{127} \mathrm{I}^{9+}$ ion beam using the set-up at Uppsala University. ${ }^{29,30}$ The recoil angle was $45^{\circ}$, with both the incident angle of primary ions and the exit angle of recoils set to $67.5^{\circ}$ relative to the surface normal. All spectra were analyzed using the CONTES code,$^{31}$ with which the recoil energy of each element was converted to relative atomic concentration profiles.

Nanoindentation was performed on a film $\sim 1 \mu \mathrm{m}$ in thickness with a Berkovich diamond tip at room temperature. The Oliver and Pharr method ${ }^{32}$ was used to calculate the hardness $(\mathrm{H})$ and the reduced Young's modulus $\left(\mathrm{E}_{\mathrm{r}}\right)$. Twenty-seven indents were made at a force of $2.6 \mathrm{mN}$. The indentation depth was around $0.09 \mu \mathrm{m}$. The stated error bars correspond to the standard deviation in the obtained $\mathrm{H}$ and $\mathrm{E}_{\mathrm{r}}$ values. Additional control measurements with varied forces were made, and no substantial differences in $\mathrm{H}$ and $\mathrm{E}_{\mathrm{r}}$ were seen.

\section{RESULTS AND DISCUSSION}

Figure 1 shows a $\theta-2 \theta$ x-ray diffractogram of a Ti/VGe-C film deposited at a Ti/V current of $310 \mathrm{~mA}(\sim 311 \mathrm{~V})$, a Ge current of $60 \mathrm{~mA}(\sim 340 \mathrm{~V})$, a C current of $370 \mathrm{~mA}$ $(\sim 660 \mathrm{~V})$, and a substrate temperature $\left(\mathrm{T}_{\mathrm{s}}\right)=800{ }^{\circ} \mathrm{C}$ on an $\mathrm{Al}_{2} \mathrm{O}_{3}$ substrate. Diffraction peaks are observed at $2 \theta$ angles of $14.09^{\circ}, 28.37^{\circ}$, and $43.09^{\circ}$. For pure $\mathrm{Ti}_{2} \mathrm{GeC}$, the 0002 , 0004 , and 0006 peaks are at $2 \theta$ angles of $13.69^{\circ}, 27.57^{\circ}$, and $41.89^{\circ}$, respectively (ICDD PDF 89-2278); these peaks for $\mathrm{V}_{2} \mathrm{GeC}$ are at $14.45^{\circ}, 29.14^{\circ}$, and $44.33^{\circ}$ (ICDD PDF

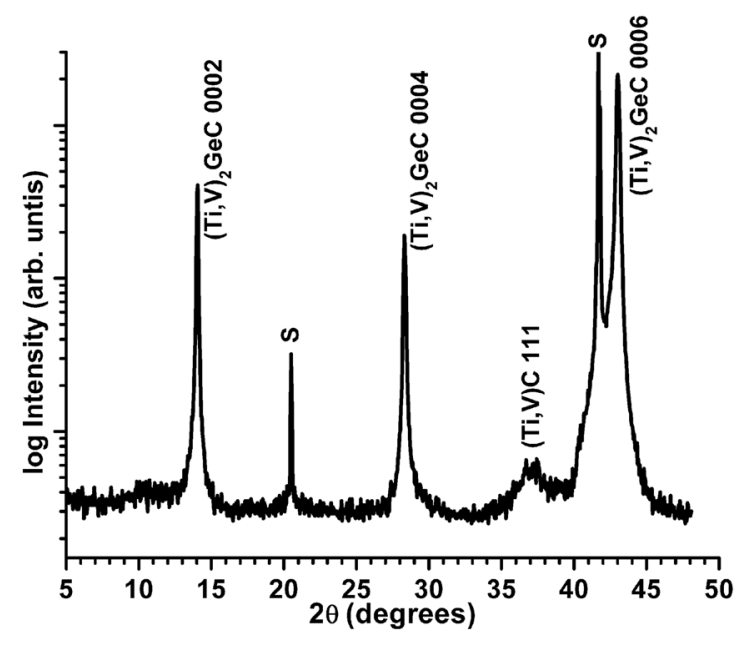

FIG. 1. X-ray diffractogram of phase-pure $(\mathrm{Ti}, \mathrm{V})_{2} \mathrm{GeC}$ films deposited onto an $\mathrm{Al}_{2} \mathrm{O}_{3}(0001)$ substrate (marked by " $\mathrm{S}$ " in the diffractogram) at a substrate temperature of $800{ }^{\circ} \mathrm{C}$. The targets were operated at $310 \mathrm{~mA}(\mathrm{Ti} / \mathrm{V}), 60 \mathrm{~mA}$ $(\mathrm{Ge})$, and $370 \mathrm{~mA}(\mathrm{C})$.

89-2276). The diffraction peaks from the Ti/V-Ge-C film are between the nominal positions for $\mathrm{Ti}_{2} \mathrm{GeC}$ and $\mathrm{V}_{2} \mathrm{GeC}$, showing that this film is a virtually phase-pure solid solution of $(\mathrm{Ti}, \mathrm{V})_{2} \mathrm{GeC}$. The broad, low-intensity peak from $(\mathrm{Ti}, \mathrm{V}) \mathrm{C}$ at $\sim 36.7^{\circ}$ mainly comes from an incubation layer formed at the initial stage of nucleation, similar to what has been observed for $\mathrm{Ti}_{3} \mathrm{SiC}_{2}{ }^{10}$ In addition, trace amounts of $(\mathrm{Ti}, \mathrm{V}) \mathrm{C}$ in the film were observed in TEM as inclusions (not shown). The $c$ lattice parameter of $(\mathrm{Ti}, \mathrm{V})_{2} \mathrm{GeC}$ determined from the XRD peak positions is $12.59 \AA$, which is between the $c$ lattice parameters of $\mathrm{Ti}_{2} \mathrm{GeC}(c=12.93 \AA)$ and $\mathrm{V}_{2} \mathrm{GeC}$ $(c=12.25 \AA)$. Assuming that Vegard's law holds, the Ti/V ratio determined from these lattice parameters is $50 / 50$, i.e., the same composition as in the Ti/V target.

Figure 2 shows $\theta-2 \theta$ XRD patterns of Ti/V-Ge-C films deposited onto $\mathrm{Al}_{2} \mathrm{O}_{3}(0001)$ with the same deposition

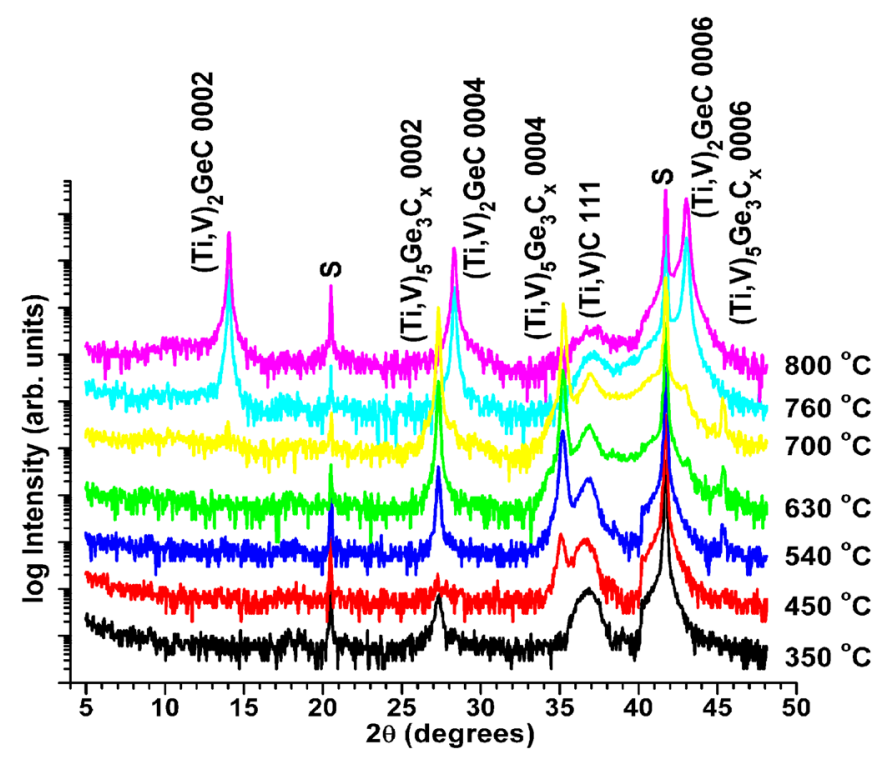

FIG. 2. (Color online) X-ray diffractograms of Ti/V-Ge-C films deposited onto $\mathrm{Al}_{2} \mathrm{O}_{3}(0001)$ substrate $(\mathrm{S})$. The targets were operated at $310 \mathrm{~mA}$ $(\mathrm{Ti} / \mathrm{V}), 60 \mathrm{~mA}(\mathrm{Ge})$, and $370 \mathrm{~mA}(\mathrm{C})$. The substrate temperature is varied from $350{ }^{\circ} \mathrm{C}$ to $800{ }^{\circ} \mathrm{C}$. The $\mathrm{T}_{\mathrm{s}}=800{ }^{\circ} \mathrm{C}$ scan is taken from Fig. 1 . 
parameters as in Fig. 1, except that $\mathrm{T}_{\mathrm{s}}$ was varied from 350 ${ }^{\circ} \mathrm{C}$ to $800{ }^{\circ} \mathrm{C}$. For $\mathrm{T}_{\mathrm{s}}=350{ }^{\circ} \mathrm{C}$, the $(\mathrm{Ti}, \mathrm{V}) \mathrm{C}$ peak is strong. For higher $\mathrm{T}_{\mathrm{s}}$, the peak intensity of $(\mathrm{Ti}, \mathrm{V}) \mathrm{C}$ decreases, and at $\mathrm{T}_{\mathrm{s}}=700{ }^{\circ} \mathrm{C}$, the $(\mathrm{Ti}, \mathrm{V})_{2} \mathrm{GeC}$ is present. There are additional peaks at $2 \theta$ angles of $27.3^{\circ}, 35.5^{\circ}$, and $46.2^{\circ}$, respectively, that can be attributed to $(\mathrm{Ti}, \mathrm{V})_{5} \mathrm{Ge}_{3} \mathrm{C}_{\mathrm{x}}$ (the peak positions are between $\mathrm{Ti}_{5} \mathrm{Ge}_{3} \mathrm{C}_{\mathrm{x}}$ and $\left.\mathrm{V}_{5} \mathrm{Ge}_{3} \mathrm{C}_{\mathrm{x}}\right) \cdot{ }^{24,25}$ Also, at $\mathrm{T}_{\mathrm{s}}=700{ }^{\circ} \mathrm{C}$, the $(\mathrm{Ti}, \mathrm{V})_{5} \mathrm{Ge}_{3} \mathrm{C}_{\mathrm{x}}$ and $(\mathrm{Ti}, \mathrm{V}) \mathrm{C}$ peaks are strong, and $(\mathrm{Ti}, \mathrm{V})_{2-}$ $\mathrm{GeC}$ is present as a minority phase. For $\mathrm{T}_{\mathrm{s}}=760{ }^{\circ} \mathrm{C}$, the $(\mathrm{Ti}, \mathrm{V})_{5} \mathrm{Ge}_{3} \mathrm{C}_{\mathrm{x}}$ peaks are not present and the $(\mathrm{Ti}, \mathrm{V}) \mathrm{C}$ peak becomes smaller, whereas $(\mathrm{Ti}, \mathrm{V})_{2} \mathrm{GeC}$ shows a high intensity. The films consist of phase-pure solid-solution $(\mathrm{Ti}, \mathrm{V})_{2}$ $\mathrm{GeC}$ at $\mathrm{T}_{\mathrm{s}}=800^{\circ} \mathrm{C}$, except for the trace amounts of $(\mathrm{Ti}, \mathrm{V}) \mathrm{C}$ mentioned above (see Fig. 1).

Table I shows the composition (determined by ERDA) of the Ti/V-Ge-C films in Fig. 2. The phase-pure $(\mathrm{Ti}, \mathrm{V})_{2-}$ GeC film grown at $\mathrm{T}_{\mathrm{s}}=800^{\circ} \mathrm{C}$ (Fig. 1) has a composition of $(\mathrm{Ti}, \mathrm{V})_{0.525} \mathrm{Ge}_{0.244} \mathrm{C}_{0.221}$, or 2:1:1 within the error bars of this technique. ERDA does not permit the separation of the Ti and $\mathrm{V}$ signals; however, according to the application of Vegard's law to the XRD results (see above), the Ti/V ratio is $50 / 50$. We can thus conclude that the phase-pure solid solution film has $\left(\mathrm{Ti}_{0.5}, \mathrm{~V}_{0.5}\right)_{2} \mathrm{GeC}$ stoichiometry.

As mentioned, the lowest reported substrate temperature of $\mathrm{Ti}_{2} \mathrm{GeC}$ is $\sim 700{ }^{\circ} \mathrm{C}\left(\sim 800{ }^{\circ} \mathrm{C}\right.$ for phase-pure $\left.\mathrm{Ti}_{2} \mathrm{GeC}\right)$, whereas $\mathrm{V}_{2} \mathrm{GeC}$ can be grown at temperatures down to $\sim 450$ ${ }^{\circ} \mathrm{C}$. Our results show that the lowest possible substrate temperature for $\left(\mathrm{Ti}_{0.5}, \mathrm{~V}_{0.5}\right)_{2} \mathrm{GeC}$ does not largely differ from that of $\mathrm{Ti}_{2} \mathrm{GeC}$, i.e., films deposited at $700{ }^{\circ} \mathrm{C}$ contain $\left(\mathrm{Ti}_{0.5}, \mathrm{~V}_{0.5}\right)_{2} \mathrm{GeC}$, whereas $\sim 800{ }^{\circ} \mathrm{C}$ is required for phasepure $\left(\mathrm{Ti}_{0.5}, \mathrm{~V}_{0.5}\right)_{2} \mathrm{GeC}$. This is surprising because, in general, the substrate temperature for MAX phases is lower for transition metals (M) from groups 5 and 6 in the periodic table. ${ }^{2,24,25,33-36}$ As previously reviewed, ${ }^{2}$ the $\mathrm{M}-\mathrm{C}$ bonding energy generally decreases going from group 4 to group 6 (e.g., from $\mathrm{Ti}$ to $\mathrm{Cr}$ ), and kinetics should therefore favor $\mathrm{M}$ and $\mathrm{C}$ diffusion in MAX phases, with group 5 and 6 transition metals (e.g., $\mathrm{V}$ and $\mathrm{Cr}$ ) requiring lower substrate temperatures for these MAX phases than the ones with group 4 transition metals. Our results indicate that this effect is not substantial for a $50 / 50 \mathrm{Ti} / \mathrm{V}$ mixture and that diffusion is not enhanced compared to the pure Ti-Ge-C system. A possible reason for this result could be that the $(\mathrm{Ti}, \mathrm{V}) \mathrm{C}$ and $(\mathrm{Ti}, \mathrm{V})_{5} \mathrm{Ge}_{3} \mathrm{C}_{\mathrm{x}}$ phase with smaller unit cells are favorably formed at these kinetically limited conditions, as is the case for the Ti-Ge-C system. ${ }^{24}$

Figure 3 shows $\mathrm{x}$-ray diffractograms of Ti/V-Ge-C films deposited on $\mathrm{Al}_{2} \mathrm{O}_{3}(0001)$ at $\mathrm{T}_{\mathrm{s}}=800{ }^{\circ} \mathrm{C}$. Table II shows the composition (determined by ERDA) of the films in Fig. 3 .

TABLE I. Composition of the Ti/V-Ge-C films in Fig. 2 (determined by ERDA).

\begin{tabular}{lrrrrrr}
\hline \hline $\mathrm{T}_{\mathrm{s}}\left({ }^{\circ} \mathrm{C}\right)$ & 350 & 450 & 540 & 700 & 760 & 800 \\
\hline (Ti,V) content (at. \%) & 46.4 & 47.1 & 46.3 & 50.6 & 51.7 & 52.5 \\
Ge content (at. \%) & 30.4 & 28.8 & 28.2 & 24.4 & 24.1 & 24.7 \\
$\mathrm{C}$ content (at. \%) & 22.9 & 22.1 & 22.5 & 23.5 & 24.1 & 22.1 \\
O content (at. \%) & 0.3 & 2.0 & 3.0 & 1.5 & 0.1 & 0.7 \\
\hline \hline
\end{tabular}

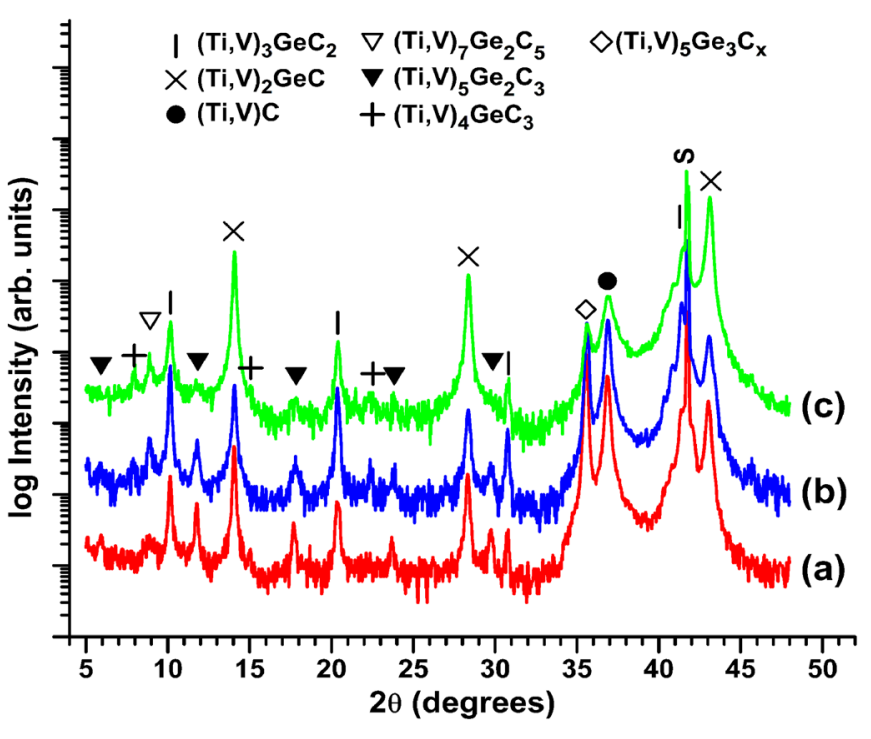

FIG. 3. (Color online) X-ray diffractograms of phase-mixed Ti/V-Ge-C MAX phase films deposited onto $\mathrm{Al}_{2} \mathrm{O}_{3}(0001)$ substrate (S) at a substrate temperature of $800^{\circ} \mathrm{C}$. The targets were operated at (a) $310 \mathrm{~mA}(\mathrm{Ti} / \mathrm{V}), 55$ $\mathrm{mA}(\mathrm{Ge})$, and $370 \mathrm{~mA}(\mathrm{C})$; (b) $310 \mathrm{~mA}(\mathrm{Ti} / \mathrm{V}), 55 \mathrm{~mA}(\mathrm{Ge})$, and $400 \mathrm{~mA}$ (C); and (c) $310 \mathrm{~mA}(\mathrm{Ti} / \mathrm{V}), 70 \mathrm{~mA}(\mathrm{Ge})$, and $400 \mathrm{~mA}(\mathrm{C})$.

Film (a), deposited under a Ti/V current of $310 \mathrm{~mA}$, a Ge current of $55 \mathrm{~mA}$, and a C current of $370 \mathrm{~mA}$, exhibits XRD peaks at $2 \theta$ angles of $10.16^{\circ}, 20.36^{\circ}, 30.76^{\circ}$, and $41.38^{\circ}$. These peaks correspond to the 0002, 0004, 0006, and 0008 peaks of $(\mathrm{Ti}, \mathrm{V})_{3} \mathrm{GeC}_{2}$. From the XRD results, the $c$ lattice parameter of this 312 phase is $17.42 \AA$. This film also shows peaks originating from $(\mathrm{Ti}, \mathrm{V})_{5} \mathrm{Ge}_{2} \mathrm{C}_{3}$, a " 523 " phase that can be described as intergrown alternating half-unit cells of 211 and 312 phases. ${ }^{2,23,24,37}$ For the film in Fig. 3(b), the $\mathrm{C}$ target current is increased from $370 \mathrm{~mA}$ to $400 \mathrm{~mA}$. The XRD pattern shows increased "312" content relative to "211." Figure 3(c) shows the XRD of a film deposited at a higher Ge flux (changed from $55 \mathrm{~mA}$ to $70 \mathrm{~mA}$ ). As expected, the amount of Ge-rich phases ("211" and " $53 x$ ") increases relative to the Ge-poor phases. Furthermore, in Figs. 3(a)-3(c), minute peaks are observed at $2 \theta$ angles of $7.88^{\circ}$ and $15.04^{\circ}$, which correspond to a small amount of $(\mathrm{Ti}, \mathrm{V})_{4} \mathrm{GeC}_{3}$. There is also diffraction from $(\mathrm{Ti}, \mathrm{V})_{7} \mathrm{Ge}_{2} \mathrm{C}_{5}$, a " 725 " phase with intergrown alternating half-unit cells of 413 and 312 phases. ${ }^{38}$

Our results (Fig. 3) show that a reduction in Ge content, compared to the phase-pure $(\mathrm{Ti}, \mathrm{V})_{2} \mathrm{GeC}$, results in the formation of $(\mathrm{Ti}, \mathrm{V})_{3} \mathrm{GeC}_{2}$ and small amounts of $(\mathrm{Ti}, \mathrm{V})_{4} \mathrm{GeC}_{3}$. The hypothetical phases $\mathrm{V}_{3} \mathrm{GeC}_{2}$ and $\mathrm{V}_{4} \mathrm{GeC}_{3}$ can thus be partially stabilized via alloying with Ti. Furthermore, it is expected that fluctuations in the local Ge growth flux can

TABLE II. Composition of the Ti/V-Ge-C films in Fig. 3 and Fig. 4 (determined by ERDA).

\begin{tabular}{|c|c|c|c|c|c|c|c|c|}
\hline \multirow[b]{2}{*}{ Film } & \multicolumn{3}{|c|}{ Target current (mA) } & \multirow[b]{2}{*}{$\mathrm{T}_{\mathrm{s}}\left({ }^{\circ} \mathrm{C}\right)$} & \multicolumn{4}{|c|}{ Composition (at. \%) } \\
\hline & $\mathrm{Ti} / \mathrm{V}$ & $\mathrm{Ge}$ & $\mathrm{C}$ & & $\mathrm{Ti} / \mathrm{V}$ & $\mathrm{Ge}$ & $\mathrm{C}$ & $\mathrm{O}$ \\
\hline $\mathrm{a}$ & 310 & 55 & 370 & 800 & 56.7 & 17.0 & 26.0 & 0.3 \\
\hline b & 310 & 55 & 400 & 800 & 54.4 & 16.5 & 28.6 & 0.5 \\
\hline $\mathrm{c}$ & 310 & 70 & 400 & 800 & 52.3 & 18.0 & 29.6 & 0.1 \\
\hline
\end{tabular}


result in mixtures of 211,312 , and 413 phases. This explains the observations of " 523 " and " 725 " intergrown phases, which are known from the Ti-Ge-C system but not the $\mathrm{V}-\mathrm{Ge}-\mathrm{C}$ system. ${ }^{2,24}$ In the binary V-C system, there are binary carbide superstructures such as $\mathrm{V}_{8} \mathrm{C}_{7}$ that might prevent the formation of 312 and 413 phases. Apparently, there is a higher tendency to form $\mathrm{V}_{2} \mathrm{GeC}$ with binary-carbide inclusions when growth fluctuations occur, ${ }^{25}$ which might explain this difference between $\left(\mathrm{Ti}_{0.5} \mathrm{~V}_{0.5}\right)_{2} \mathrm{GeC}$ and $\mathrm{V}_{2} \mathrm{GeC}$.

Figure 4 shows XRD patterns of Ti/V-Ge-C films deposited on (a) $4 \mathrm{H}-\mathrm{SiC}(0001)$ and (b) $\mathrm{Al}_{2} \mathrm{O}_{3}(0001)$ substrates using identical growth conditions ( $\mathrm{Ti} / \mathrm{V}$ current of $310 \mathrm{~mA}$ $(\sim 301 \mathrm{~V})$, Ge current of $80 \mathrm{~mA}(\sim 330 \mathrm{~V}), \mathrm{C}$ current of 370 $\mathrm{mA}(\sim 720 \mathrm{~V})$, and $\left.\mathrm{T}_{\mathrm{s}}=800{ }^{\circ} \mathrm{C}\right)$ in the same deposition batch in geometrically equivalent positions in the rotating substrate holder. The XRD results (Fig. 4(a)) show that the film deposited onto $\mathrm{Al}_{2} \mathrm{O}_{3}(0001)$ is a "211"-“"523"-“312" phase-mixture. In contrast, the $\mathrm{Ti} / \mathrm{V}-\mathrm{Ge}-\mathrm{C}$ film grown on $4 \mathrm{H}-\mathrm{SiC}(0001)$ exhibits a dominant $(\mathrm{Ti}, \mathrm{V})_{3} \mathrm{GeC}_{2}$ phase with only minor amounts of $(\mathrm{Ti}, \mathrm{V})_{2} \mathrm{GeC}$. The ERDA results for this film showed that the overall composition is 51.7 at. \% $\mathrm{Ti} / \mathrm{V}, 16.7$ at. $\% \mathrm{Ge}$, and 31.6 at. \% C, or 3:1:2 within the accuracy of the technique. Because everything else is equal, these results show that the substrate affects the growth of $\mathrm{Ti} / \mathrm{V}-\mathrm{Ge}-\mathrm{C}$ films. There is no epitaxial match by low integer number ratio between the $c$-axis height of $(\mathrm{Ti}, \mathrm{V})_{3} \mathrm{GeC}_{2}$ and the step heights ${ }^{39,40}$ on the $4 \mathrm{H}-\mathrm{SiC}$ substrates; therefore, a direct effect of the epitaxy conditions on nucleation cannot explain this observation. The difference should rather be related to enhanced diffusion on $4 \mathrm{H}-\mathrm{SiC}$ as compared to $\mathrm{Al}_{2} \mathrm{O}_{3}$. This is possible, because $\mathrm{SiC}$ is a far better thermal conductor than $\mathrm{Al}_{2} \mathrm{O}_{3}$, and the actual local surface temperature might be higher for the case of deposition onto $\mathrm{SiC}$ than for deposition onto $\mathrm{Al}_{2} \mathrm{O}_{3}$. This would favor the formation of the larger-unit-cell phase $(\mathrm{Ti}, \mathrm{V})_{3} \mathrm{GeC}_{2}$.

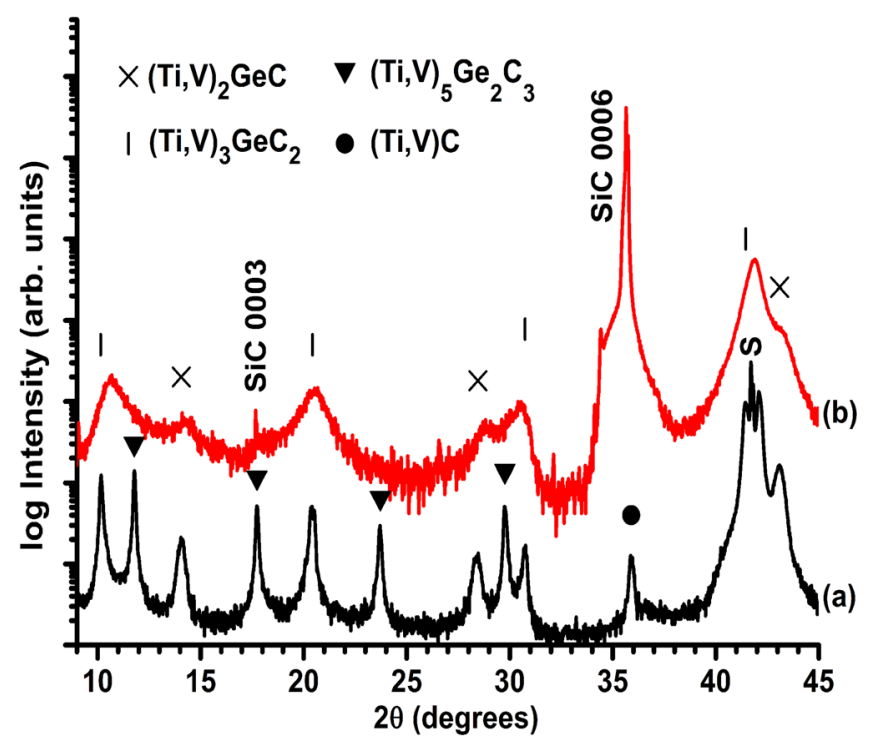

FIG. 4. (Color online) X-ray diffractograms of phase-mixed Ti/V-Ge-C MAX phase films deposited onto (a) $4 \mathrm{H}-\mathrm{SiC}(0001)$ and (b) $\mathrm{Al}_{2} \mathrm{O}_{3}(0001)$ substrates, with the $\mathrm{Al}_{2} \mathrm{O}_{3}(0001)$ substrate peak indicated by "S." Both films were grown at the same time. The targets were operated at $310 \mathrm{~mA}(\mathrm{Ti} / \mathrm{V})$, $80 \mathrm{~mA}(\mathrm{Ge})$, and $370 \mathrm{~mA}(\mathrm{C})$. The substrate temperature was kept at $800{ }^{\circ} \mathrm{C}$.
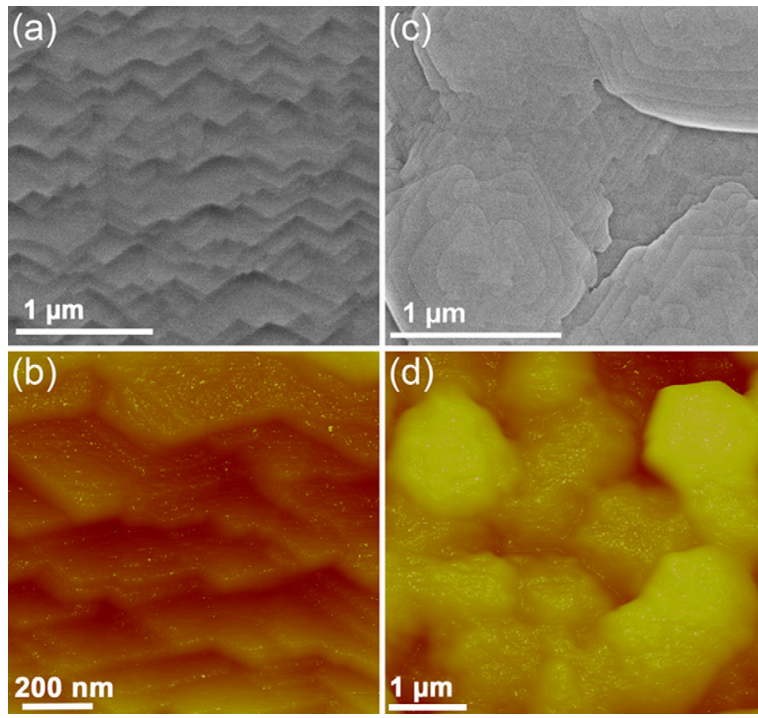

FIG. 5. (Color online) SEM and AFM images of phase mixed Ti/V-Ge-C MAX phase films with different substrates (a),(b) on $4 \mathrm{H}-\mathrm{SiC}(0001)$ and (c),(d) on $\mathrm{Al}_{2} \mathrm{O}_{3}(0001)$.

Figures 5(a) and 5(b) show SEM and AFM images, respectively, of the surface morphology of the phase mixed $\mathrm{Ti} / \mathrm{V}-\mathrm{Ge}-\mathrm{C}$ film on $4 \mathrm{H}-\mathrm{SiC}$ substrate. Both techniques show stacked layers with steps, which are of the $\{11 \overline{2} 0\}$ family. ${ }^{41}$ The off cut of the $4 \mathrm{H}-\mathrm{SiC}$ substrate presents growth steps for the films generating the step-flow growth mode on the film (0001) surface, similar to $\mathrm{Ti}_{3} \mathrm{SiC}_{2}$ films on $4 \mathrm{H}-\mathrm{SiC}(0001){ }^{41}$ However, the growth of $\mathrm{Ti}_{3} \mathrm{SiC}_{2}$ films requires Sisupersaturated conditions in order to maintain the faceted steps ${ }^{41}$ whereas the supersaturated condition is not required for such growth of the Ti/V-Ge-C system. This might be due to the difference in the diffusivity of $\mathrm{Si}$ and Ge. However, the phase mixed Ti/V-Ge-C film on $\mathrm{Al}_{2} \mathrm{O}_{3}$ substrate has a completely different surface morphology from the film grown on $4 \mathrm{H}-\mathrm{SiC}$ [see the SEM and AFM images in Figs. 5(c) and 5(d), respectively]. The SEM image shows that the film has spiral-growth steps from threading screw dislocation. This growth mode has also been seen in the Ti-Si-C system. ${ }^{10}$

Figure 6 shows cross-sectional TEM images of the phase-mixed Ti/V-Ge-C MAX phase film on $\mathrm{Al}_{2} \mathrm{O}_{3}(0001)$ grown under the same conditions as in Fig. 3(a). Figure 6(a) shows an overview, and Fig. 6(b) is a high-resolution TEM image showing the nanolaminated structure of $(\mathrm{Ti}, \mathrm{V})_{2} \mathrm{GeC}$ with the $c$ lattice parameter $\left(c_{211}\right)$ measured to $12.5 \AA$. The film also has regions of $(\mathrm{Ti}, \mathrm{V})_{3} \mathrm{GeC}_{2}$ (Fig. 6(c)) where the $c$ lattice parameter is measured $\left(c_{312}\right)$ to $17.4 \AA$. These values differ slightly from the more reliable values obtained from $\mathrm{XRD}$, given the degree of error in the lattice parameter determination in TEM.

The hardness and reduced Young's modulus were measured via nanoindentation for $1-\mu \mathrm{m}$-thick phase-mixed (Ti,V)-Ge-C MAX-phase film (XRD pattern similar to Fig. $3(\mathrm{c})$ ). The values obtained from nanoindentation are $12.4 \pm 0.9 \mathrm{GPa}$ and $241 \pm 15 \mathrm{GPa}$, respectively. Our determined hardness values are considerably higher than the values measured on bulk polycrystalline MAX phase materials, 


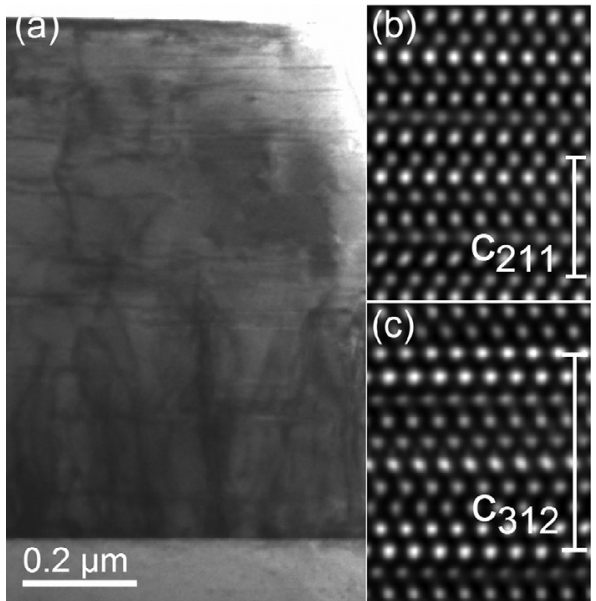

FIG. 6. Cross-sectional TEM images from a phase-mixed Ti/V-Ge-C film (a) in an overview, and (b),(c) high resolution images of 211 and 312 MAX phases. The lattice parameters $c_{211}$ and $c_{312}$ have lengths of $12.5 \AA$ and 17.4 $\AA$ in (b) and (c), respectively.

which are around 2 to $5 \mathrm{GPa} .{ }^{1}$ However, in thin films, the measured hardness values are typically higher because of indentation size effects and possible anisotropy effects. ${ }^{2}$ Our measured hardness of $12.4 \pm 0.9 \mathrm{GPa}$ is a rather typical number and does not indicate (or disprove) any solid solution hardening. In addition, small amounts of binary-carbide inclusions inside the film are known to affect the determination of mechanical properties, ${ }^{25,42}$ which might also affect the present values.

\section{CONCLUSIONS}

Phase-pure $\left(\mathrm{Ti}_{0.5} \mathrm{~V}_{0.5}\right)_{2} \mathrm{GeC}$ thin films can be grown using dc magnetron sputtering on $\mathrm{Al}_{2} \mathrm{O}_{3}(0001)$ substrates at a substrate temperature of $800{ }^{\circ} \mathrm{C}$. The $c$ lattice parameter of $(\mathrm{Ti}, \mathrm{V})_{2} \mathrm{GeC}$ is $12.59 \AA$, which is between those of $\mathrm{Ti}_{2} \mathrm{GeC}$ $(c=12.93 \AA)$ and $\mathrm{V}_{2} \mathrm{GeC}(c=12.25 \AA)$. The $\mathrm{Ti} / \mathrm{V}$ ratio determined from these lattice parameters is $50 / 50$. The substrate temperature that is required for the epitaxial growth of $(\mathrm{Ti}, \mathrm{V})_{2} \mathrm{GeC}$ is similar to that for $\mathrm{Ti}_{2} \mathrm{GeC}\left(\mathrm{T}_{\mathrm{s}}=700{ }^{\circ} \mathrm{C}\right)$. The hypothetical phases $\mathrm{V}_{3} \mathrm{GeC}_{2}$ and $\mathrm{V}_{4} \mathrm{GeC}_{3}$ are realized by alloying with $\mathrm{Ti}$. In contrast, $\mathrm{Ti} / \mathrm{V}-\mathrm{Ge}-\mathrm{C}$ films grown on $4 \mathrm{H}-$ $\mathrm{SiC}$ under otherwise identical conditions have $(\mathrm{Ti}, \mathrm{V})_{3} \mathrm{GeC}_{2}$ as the dominant phase; the suggested underlying mechanism is the difference in the local substrate temperatures of $\mathrm{Al}_{2} \mathrm{O}_{3}$ and $\mathrm{SiC}$, which enhances surface diffusion and facilitates the growth of the higher-order phase $(\mathrm{Ti}, \mathrm{V})_{3} \mathrm{GeC}_{2}$ compared to $(\mathrm{Ti}, \mathrm{V})_{2} \mathrm{GeC}$.

\section{ACKNOWLEDGMENTS}

We acknowledge funding from the Swedish Research Council (VR) and the Swedish Agency for Innovation Systems (VINNOVA) Excellence Center FunMat. Dr. Jenny Frodelius is acknowledged for nanoindentation measurements.

${ }^{1}$ M. W. Barsoum, Prog. Solid State Chem. 28, 201 (2000).

${ }^{2}$ P. Eklund, M. Beckers, U. Jansson, H. Högberg, and L. Hultman, Thin Solid Films 518, 1851 (2010).

${ }^{3}$ J. Wang and Y. Zhou, Annu. Rev. Mater. Res. 39, 415 (2009).
${ }^{4}$ L. Zheng, J. Wang, X. Lu, F. Li, and Y. Zhou, J. Am. Ceram. Soc. 93, 3068 (2010).

${ }^{5}$ F. L. Meng, Y. C. Zhou, and J. Y. Wang, Scr. Mater. 53, 1369 (2005).

${ }^{6}$ N. A. Phatak, S. K. Saxena, Y. Fei, and J. Hu, J. Alloys Compd. 475, 629 (2009).

${ }^{7}$ I. Salama, T. El-Raghy, and M. W. Barsoum, J. Alloys Compd. 347, 271 (2002).

${ }^{8}$ J. Yi, P. Chena, D. Li, X. Xiao, W. Zhanga, and B. Tang, Solid State Commun. 150, 49 (2010).

${ }^{9}$ B. Manoun, S. K. Saxena, G. Huga, A. Ganguly, E. N. Hoffman, and M. W. Barsoum, J. Appl. Phys. 101, 113523 (2007).

${ }^{10}$ J. Emmerlich, H. Högberg, S. Sasvári, P. O. A. Persson, L. Hultman, J. P. Palmquist, U. Jansson, J. M. Molina-Aldareguia, and Z. Czigány, J. Appl. Phys. 96, 4817 (2004).

${ }^{11}$ P. Eklund, A. Murugaiah, J. Emmerlich, Z. Czigàny, J. Frodelius, M. W. Barsoum, H. Högberg, and L. Hultman, J. Cryst. Growth 304, 264 (2007).

${ }^{12}$ D. P. Sigumonrong, J. Zhang, Y. Zhou, D. Music, J. Emmerlich, J. Mayer, and J. M. Schneider, Scr. Mater. 64, 347 (2011).

${ }^{13}$ D. P. Sigumonrong, J. Zhang, Y. Zhou, D. Music, and J. M. Schneider, J. Phys. D: Appl. Phys. 42, 185408 (2009).

${ }^{14}$ J. Emmerlich, P. Eklund, D. Rittrich, H. Högberg, and L. Hultman, J. Mater. Res. 22, 2279 (2007).

${ }^{15}$ J. Frodelius, P. Eklund, M. Beckers, P. O. Å. Persson, H. Högberg, and L. Hultman, Thin Solid Films 518, 1621 (2010).

${ }^{16}$ M. D. Tucker, P. O. Å. Persson, M. C. Guenette, J. Rosén, M. M. M. Bilek, and D. R. McKenzie, J. Appl. Phys. 109, 014903 (2011).

${ }^{17}$ T. H. Scabarozi, C. Gennaoui, J. Roche, T. Flemming, K. Wittenberger, P. Hann, B. Adamson, A. Rosenfeld, M. W. Barsoum, J. D. Hettinger, and S. E. Lofland, Appl. Phys. Lett. 95, 101907 (2009).

${ }^{18}$ J. Rosén, P. O. Å. Persson, M. Ionescu, A. Kondyurin, D. R. McKenzie, and M. M. M. Bilek, Appl. Phys. Lett. 92, 064102 (2008).

${ }^{19}$ O. Wilhelmsson, J. P. Palmquist, E. Lewin, J. Emmerlich, P. Eklund, P. O. A. Persson, H. Högberg, S. Li, R. Ahuja, O. Eriksson, L. Hultman, and U. Jansson, J. Cryst. Growth 291, 290 (2006).

${ }^{20}$ P. O. A. Persson, J. Rosén, D. R. McKenzie, M. M. M. Bilek, and C. Höglund, J. Appl. Phys. 103, 066102 (2008).

${ }^{21}$ M. Magnuson, O. Wilhelmsson, M. Mattesini, S. Li, R. Ahuja, O. Eriksson, H. Högberg, L. Hultman, and U. Jansson, Phys. Rev. B 78, 035117 (2008).

${ }^{22}$ T. H. Scabarozi, P. Eklund, J. Emmerlich, H. Högberg, T. Meehan, P. Finkel, M. W. Barsoum, J. D. Hettinger, L. Hultman, and S. E. Lofland, Solid State Commun. 146, 498 (2008).

${ }^{23}$ H. Högberg, L. Hultman, J. Emmerlich, T. Joelsson, P. Eklund, J. M. Molina-Aldareguia, J.-P. Palmquist, O. Wilhelmsson, and U. Jansson, Surf. Coat. Technol. 193, 6 (2005).

${ }^{24}$ H. Högberg, P. Eklund, J. Emmerlich, J. Birch, and L. Hultman, J. Mater. Res. 20, 779 (2005).

${ }^{25}$ O. Wilhelmsson, P. Eklund, H. Högberg, L. Hultman, and U. Jansson, Acta Mater. 56, 2563 (2008).

${ }^{26}$ SiCrystal AG, Guenther-Scharowsky-Str.1, D 91058 Erlangen, Germany.

${ }^{27}$ More information about the Institute (Acreo AB, Electrum 239, 16440 Kista, Sweden) can be found at http://www.acreo.se/.

${ }^{28}$ K. Buchholt, R. Ghandi, M. Domeij, C. M. Zetterling, J. Lu, P. Eklund, L. Hultman, and A. L. Spetz, Appl. Phys. Lett. 98, 042108 (2011).

${ }^{29}$ H. J. Whitlow, G. Possnert, and C. S. Petersson, Nucl. Instrum. Methods Phys. Res. B 27, 448 (1987).

${ }^{30}$ J. Jensen, D. Martin, A. Surpi, and T. Kubart, Nucl. Instrum. Methods Phys. Res. B 268, 1893 (2010).

${ }^{31}$ M. S. Janson, "CONTES, Conversion of Time-Energy Spectra, a Program for ERDA Data Analysis," Internal Report, Uppsala University, 2004.

${ }^{32}$ W. C. Oliver and G. M. Pharr, J. Mater. Res. 7, 1564 (1992).

${ }^{33}$ A. Abdulkadhim, M. to Baben, T. Takahashi, V. Schnabel, M. Hans, C. Polzer, P. Polcik, and J. M. Schneider, Surf. Coat. Technol. (in press).

${ }^{34}$ J. J. Li, L. F. Hu, F. Z. Li, M. S. Li, and Y. C. Zhou, Surf. Coat. Technol. 204, 3838 (2010).

${ }^{35}$ Q. M. Wang, A. Flores Renteria, O. Schroeter, R. Mykhaylonka, C. Leyens, W. Garkas, and M. to Baben, Surf. Coat. Technol. 204, 2343 (2010).

${ }^{36}$ P. Eklund, M. Bugnet, V. Mauchamp, S. Dubois, C. Tromas, J. Jensen, L. Piraux, L. Gence, M. Jaouen, and T. Cabioc'h, Phys. Rev. B 84, 075424 (2011).

${ }^{37}$ J. P. Palmquist, S. Li, P. O. A. Persson, J. Emmerlich, O. Wilhelmsson, H. Högberg, M. I. Katsnelson, B. Johansson, R. Ahuja, O. Eriksson, L. Hultman, and U. Jansson, Phys. Rev. B 70, 165401 (2004). 
${ }^{38}$ T. H. Scabarozi, J. D. Hettinger, S. E. Lofland, J. Lu, L. Hultman, J. Jensen, and P. Eklund, Scripta. Mater. (in press).

${ }^{39}$ B. E. Landini and G. R. Brandes, Appl. Phys. Lett. 74, 2632 (1999).

${ }^{40}$ T. Kimoto, A. Itoh, and H. Matsunami, Appl. Phys. Lett. 66, 3645 (1995).
${ }^{41}$ K. Buchholt, P. Eklund, J. Jensen, J. Lu, A. Lloyd Spetz, and L. Hultman, Scr. Mater. 64, 1141 (2011).

${ }^{42}$ O. Wilhelmsson, P. Eklund, F. Giuliani, H. Hogberg, L. Hultman, and U. Jansson, Appl. Phys. Lett. 91, 123124 (2007). 